\title{
IMPROVING THE INTESTINAL MUCOSAL CELL UPTAKE OF WATER INSOLUBLE COMPOUNDS*
}

\section{G.L. Amidon}

The University of Michigan, College of Pharmacy, Ann Arbor, MI 48109.1065 (U.S.A.) and SmithKline Consumer Products, P.O. Box 8082, Philadelphia, PA 19101 (U.S.A.)

\section{B.H. Stewart**}

The University of Michigan, College of Pharmacy, Ann Arbor, MI $48109-1065$ (U.S.A.)

and S. Pogany

INTERx Research Corp., Lawrence, KS 66044 (U.S.A.)

A significant increase in intestinal mucosal cell uptake rate can be achieved by making brush border enzyme-labile derivatives of water insoluble compounds. The test compounds chosen were decanol, hexadecanol, their corresponding lysinate esters, hydrocortisone and its phosphate and succinate esters. Intestinal perfusion and intestinal ring uptake experiments in the alcohol study demonstrated that prodrug uptake was comparable to uptake of the free alcohol below the solubility of the parent compound; i.e., there was little or no loss in intestinal permeability. Prodrug uptake continued to increase linearly above the solubility of the free alcohol in the ring system. Similar results were obtained for hydrocortisone and its prodrugs when uptake was examined in the intestinal ring system; furthermore, rapid post-incubation freezing of the tissue coupled with an HPLC assay capable of separating drug from prodrug permitted determination of the species absorbed. In all cases, only free alcohol was detected in the tissue. Histological studies verified the integrity of intestinal tissue under experimental conditions. The in vitro technique is advantageous for screening drug absorption. The very substantial potential of this prodrug approach is demonstrated in particular with hexadecanol and hexadecyl lysinate, where the uptake rate of the prodrug was four orders of magnitude greater than that of the free alcohol.

\section{BACKGROUND}

The gastrointestinal absorption of poorly water soluble drugs is often erratic and results in highly variable blood levels and bioavailability. In part, this is a function of slow dissolution of the solid which is dependent on the

\footnotetext{
*Paper presented at the Second International Symposium on Recent Advances in Drug Delivery Systems, February 27, 28 and March 1, 1985, Salt Lake City, UT, U.S.A.

**To whom correspondence should be addressed.
}

dissolution rate constant, as well as the concentration gradient from the saturated concentration of the drug at the solid surface to the bulk concentration in the intestinal lumen [1]. For weak acids and bases, lumenal concentrations are also a function of $\mathrm{pH}$ and therefore can be expected to vary along the $\mathrm{pH}$ gradient in the intestinal tract [2]. In addition, individual variation in gastrointestinal transit times will affect the percentage of drug dissolved and hence, the amount available for absorption. 
One solution to the problem of low aqueous solubility is to produce a more polar prodrug with resultant higher aqueous solubility [3]. This method generally requires reconversion to the parent drug to obtain the original pharmacological activity. The site of reconversion in the body is important for several reasons: (a) hydrolysis of the prodrug to the parent drug and its possible precipitation should be minimized prior to absorption from the gut; and (b) the diffusion/transport advantages of the nonpolar parent drug through lipoidal membranes should not be compromised.

Under sink conditions in the blood, the maximal flux at the absorbing membrane, $J_{\mathrm{m}}$, is limited by the solubility of the compound [4] :

$J_{\mathrm{m}}=P_{\mathrm{eff}} C_{\mathrm{s}}$

where $P_{\text {eff }}$ is the effective permeability and $C_{\mathrm{s}}$ is the solubility concentration in the bulk solution. A prodrug approach which addresses the above considerations proposed [4] a drug derivative designed as a substrate for membrane-bound enzymes in the small intestine (Fig. 1). With reconversion

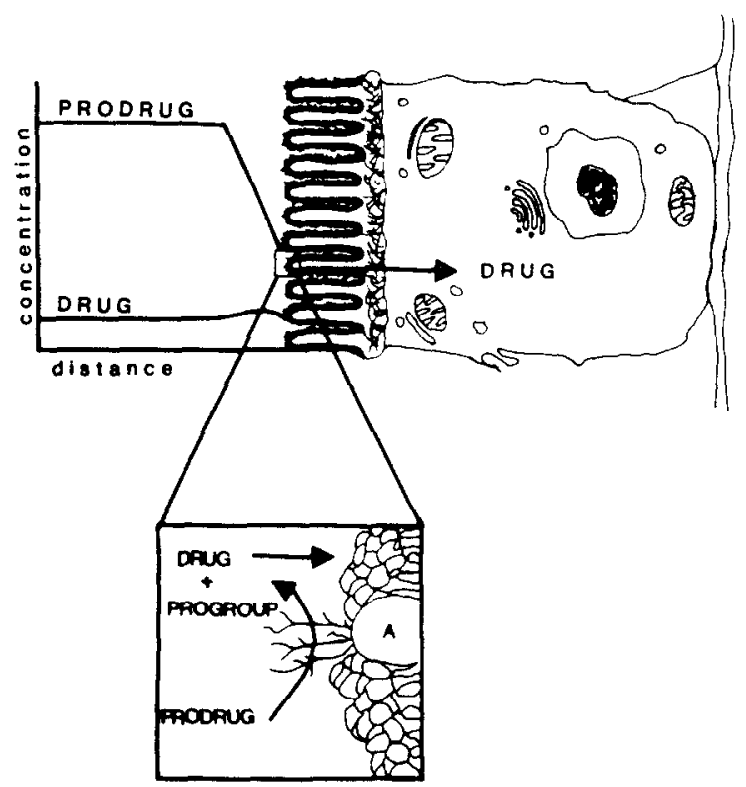

Fig. 1. Proposed mechanism for improving oral absorption of water insoluble compounds. occurring in close proximity to the membrane, the higher partition coefficient of the parent drug into the membrane should minimize precipitation in the lumen. Furthermore, the effective permeability of the prodrug should not be significantly less than that of the drug if the wall reconversion is rapid [4]. Of particular significance is the high solubility of the prodrug, which increases the concentration gradient from the intestinal lumen to the wall and therefore the chemical driving force for reaction/absorption at the wall. Since the solubility of the derivative can be orders of magnitude higher than that of the parent compound, large increases in absorption rate are possible with this approach.

Increased knowledge of the distribution and specificities of certain gut digestive enzyme systems suggests a prodrug design strategy in which the derivative contains an enzyme-labile linkage [5]. Brush borderbound enzymes of particular interest for site-specific targeting include aminopeptidases, dipeptidases [6-8] and alkaline phosphatase [9]. Phosphate prodrugs are much more water soluble than the parent drugs at intestinal $\mathrm{pH}$ due to the negative charges of the progroup and are stable in aqueous solution [10], while amino acid derivatization provides the possibility of a wide range of physical property modifications, as well as releasing nontoxic substances upon hydrolysis. Lysine derivatives have been shown to be good substrates for intestinal brush border aminopeptidase. This was substantiated in studies utilizing the in situ rat intestinal perfusion system in the presence and $a b$ sence of aminopeptidase inhibitors $[11,12]$. These studies observed that a free alpha amino group was an essential requirement for enzymatic hydrolysis of amino acid $\beta$-naphthylamine derivatives. Other strategies can be used to increase membrane permeability [5]. For example, Shindo et al. [13] demonstrated with the pivaloyloxymethyl ester of ampicillin that the high nonspecific esterase activity associated with the rat intestine was primarily localized in the 
intracellular compartments of the mucosal cell. Pivampicillin was rapidly absorbed from the lumen in its intact form and hydrolyzed to ampicillin in the mucosa. The strategy presented in this paper, however, utilizes phosphate, lysinate and succinate progroups to impart a significant polar contribution to the prodrug and substantially increase aqueous solubility. Water insoluble compounds containing amino, hydroxyl or carboxylic acid moieties are good candidates for the drug components.

In this report the potential of the above prodrug strategy is investigated using decanol, hexadecanol and hydrocortisone as the parent compounds of low aqueous solubility (0.2 $\mathrm{m} M, 0.2 \mu M$ and $0.77 \mathrm{~m} M$, respectively [14]). Lysine esters of both alcohols were synthesized. Hydrocortisone-21-succinate and 21phosphate were available commercially. Decanol and decyl lysinate were tested in an in situ rat intestinal perfusion system and all seven compounds were examined in an in vitro rat intestinal ring system $[15,16]$ which allowed study both below and above the solubilities of the parent compounds. An HPLC assay was developed which resolved the three steroids after extraction from tissue. Coupled with rapid, post-incubation freezing of the tissue and incubation media, this permitted investigation of (a) the possibility of bulk prodrug hydrolysis or back-diffusion from the membrane, and (b) the nature of the species transferred into the tissue, i.e., drug or intact prodrug.

Tissue integrity under the conditions of intestinal perfusions, intestinal ring preparation, incubation and exposure to high concentrations of surface-active agent was examined. This was accomplished by monitoring extracellular water content and by light microscopic evaluation.

\section{EXPERIMENTAL}

\section{Materials}

1-Decanol, 1-hexadecanol (Aldrich Chem. Co., Milwaukee, WI), hydrocortisone, its 21-phosphate disodium salt and 21-hemisuccinate sodium salt (Sigma Chem. Co., St. Louis, MO) and $\left[{ }^{14} \mathrm{C}\right] 1$-decanol, $\left[{ }^{14} \mathrm{C}\right] 1$ hexadecanol (ICN, Irvine, CA) and $\left[{ }^{14} \mathrm{C}\right] \mathrm{PEG}$ 4000 (DuPont-NEN, Boston, MA) were used as received. The internal standard used for gas chromatography analysis of decanol was 1-undecanol and for HPLC analysis of the steroids $\Delta^{4}$-pregnene-17 $\alpha-20 \beta, 21$-triol-3,11dione. All chemicals were of HPLC or analytical reagent grade and used as received with the exception of methylene chloride, which was purified by glass distillation at $38^{\circ} \mathrm{C}$.

Procedure for the synthesis of radioactive decyl and hexadecyl lysinate dihydrochlorides, I and II
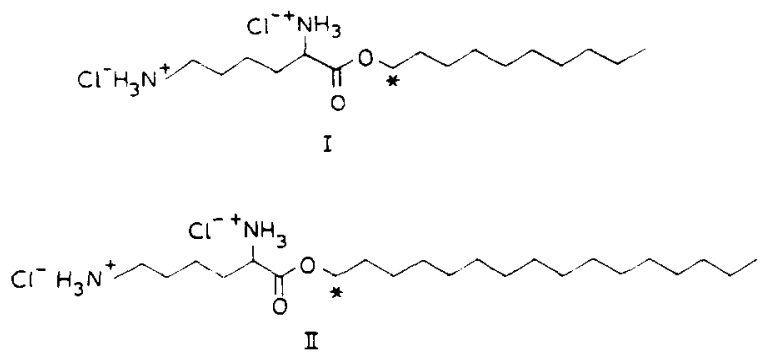

$N, N^{\prime}$-Di-t-BOC-L-lysine free carboxylic acid $(0.2 \mathrm{mmol})$ and $0.2 \mathrm{mmol}$ of $\left[{ }^{14} \mathrm{C}\right] 1$-decanol or $\left[{ }^{14} \mathrm{C}\right] 1$-hexadecanol was dissolved in 2 $\mathrm{ml}$ of dichloromethane. To the stirred solution at $25^{\circ} \mathrm{C}$ was added $0.2 \mathrm{mmol}$ of dicyclohexylcarbodiimide and $0.02 \mathrm{mmol}$ of 4 -dimethylaminopyridine as an acylation catalyst. The reaction was completed in about $10 \mathrm{~min}$ as shown by TLC analysis (silica gel plate, solvent $10 \%$ ethyl acetate/dichloromethane) which revealed total consumption of starting materials and formation of a new major spot. Solid materials were removed by filtration and the solvent was evaporated to give crude material which, after chromatography on silica gel (eluting with $10 \%$ ethyl acetate/dichloromethane), yielded a colorless oil homogeneous by TLC. This oil was dissolved in $3-4 \mathrm{ml}$ of anhydrous ethyl ether contain. ing gaseous hydrogen chloride to remove the $\mathrm{t}$-BOC protective groups from the lysine nitrogens. The solution was stirred at $25^{\circ} \mathrm{C}$ for $24 \mathrm{~h}$; the solvent was evaporated under 
vacuum. Ethyl ether and ethanol were added and then removed under vacuum several times to remove residual hydrogen chloride. Finally, the product was recrystallized from a mixture of ethanol and ether. The esters obtained in this procedure were the dihydrochloride salts. No unreacted decanol was detectable in the product using gas liquid chromatography. Elemental analysis of decyl lysinate $\left(\mathrm{C}_{16} \mathrm{H}_{36} \mathrm{~N}_{2} \mathrm{O}_{2} \mathrm{Cl}_{2}\right)$ was calculated as $\mathrm{C}=53.47, \mathrm{H}=10.10, \mathrm{~N}=7.79$ and was found to be $\mathrm{C}=53.70, \mathrm{H}=10.50$, $\mathrm{N}=7.40$. Infrared spectra (Nujol mull, Aldrich Chem. Co.) were identical for radioactive and nonradioactive analogs, demonstrating the $\mathrm{NH}_{3}$ bond at $3300-2800 \mathrm{~cm}^{-1}$ and ester carbonyl absorption at $1740 \mathrm{~cm}^{-1}$.

\section{In situ rat intestinal perfusion studies}

Rats were anesthesized with urethane $(50 \% \mathrm{w} / \mathrm{v}, 150 \mathrm{mg} / 100 \mathrm{~g}$, IM) after fasting for $20-24 \mathrm{~h}$ with water ad libitum. The upper small intestine was exposed by a midline longitudinal incision. A proximal glass cannula was inserted approximately $2 \mathrm{~cm}$ below the ligament of Treitz and was connected to a Harvard withdrawal/infusion pump (Harvard Apparatus Co., S. Natick, MA). A second cannula was positioned $6-10 \mathrm{~cm}$ distal to the first cannula for an exit tubing and led to a collection tube.

Sorenson's phosphate buffer ( $\mathrm{pH}$ 7.2) was perfused through the intestine for 30 $\mathrm{min}$ at a flow rate of 0.247 or $0.382 \mathrm{ml} / \mathrm{min}$. This was immediately followed by perfusion at the same flow rate of decanol or freshly prepared decyl lysinate/buffer solutions (nonradiolabeled) at concentrations below the solubility of decanol. These solutions were perfused $60-75 \mathrm{~min}$ with collection over 15 min intervals.

\section{Gas chromatography analysis of decanol}

Perfusate samples containing decyl lysinate were analyzed for decanol content after alkaline hydrolysis with $1 N$ sodium hy- droxide. Samples were extracted twice with equal volumes of methylene chloride containing the internal standard. The extraction efficiency from buffer was 97.0 $\pm 0.5 \%$ and $93.2 \pm 0.7 \%$ from plasma. The extracts were injected into a Perkin-Elmer gas chromatograph, Model 3920 (Norwalk, CT) with the injection block set at $230^{\circ} \mathrm{C}$. The instrument was interfaced with a Nuclear Chicago electrometer, Model 7221 (Des Plaines, IL) and a Linear recorder (Irvine, CA). Detection was by flame ionization at $250^{\circ} \mathrm{C}$. The glass columns were packed with Superpak 20M (Analabs Inc., New Haven, CT). A 2 min isothermal period at $90^{\circ} \mathrm{C}$, followed by a $90-120^{\circ} \mathrm{C}$ linear ramp at $2^{\circ} \mathrm{C}$ min was an optimal temperature program. Nitrogen was the carrier gas.

\section{Calculation of intestinal permeabilities}

Effective permeability values, $P_{\text {eff }}$, were obtained from the experimentally obtained $C_{\mathrm{m}} / C_{\mathrm{o}}$ values by the following relation

$P_{\mathrm{eff}}^{*}=\left[\ln \left(C_{\mathrm{m}} / C_{\mathrm{o}}\right)_{\exp }\right] /-4 G_{\mathrm{z}}$

where $G_{\mathrm{z}}$ is $\pi D L / 2 Q, L$ is the intestinal length, $D$ is the diffusion coefficient [17], $Q$ is the flow rate, and $C_{\mathrm{m}} / C_{\mathrm{o}}$ is the ratio of perfusate concentration exiting the intestine to the concentration of the inlet tubing.

Aqueous permeability values, ${ }^{\circ} P_{\mathrm{aq}}^{*}$, were calculated from the analytic solution of the mass balance equation [18]

$$
\begin{aligned}
& { }^{\circ} P_{\mathrm{aq}}^{*}=\left[\ln \left(C_{\mathrm{m}} / C_{\mathrm{o}}\right)_{\mathrm{th}}\right] /-4 G_{\mathrm{z}} \\
& \left(C_{\mathrm{m}} / C_{\mathrm{o}}\right)_{\mathrm{th}}=\sum_{n=1}^{5}{ }^{\circ} M_{n} \exp \left(-{ }^{\circ} B_{n}^{2} G_{\mathrm{z}}\right)
\end{aligned}
$$

where ${ }^{\circ} M_{n},{ }^{\circ} B_{n}$ are functions of the wall permeability, ${ }^{\circ}$ and $*$ indicate sink conditions and dimensionless quantities, respectively, and $\left(C_{\mathrm{m}} / C_{\mathrm{o}}\right)_{\text {th }}$ represents the theoretical value calculated for exiting to inlet concentrations [19].

${ }^{\circ} P_{\mathrm{w}}^{*}$ may be separated from the effective 
permeability using a series resistance sum for the radial transport of solute in the intestine assuming laminar flow $[4,19]$ :

$R_{\mathrm{eff}}^{*}=R_{\mathrm{aq}}^{*}+R_{\mathrm{w}}^{*}$

where the resistance, $R$, is the reciprocal of the permeability. When ${ }^{\circ} P_{\mathrm{w}}^{*} \gg{ }^{\circ} P_{\mathrm{aq}}^{*}$, the method becomes insensitive to the actual ${ }^{\circ} P_{\mathrm{w}}^{*}$ value [4].

\section{In vitro intestinal ring studies}

Male rats, fasted $24 \mathrm{~h}$ with water ad libitum, were sacrificed by anoxis. Fifteen to $20 \mathrm{~cm}$ of upper small intestine (jejunum) was removed immediately, placed in oxygenated Krebs-Henseleit buffer and everted on a glass rod. Incubations were performed in a shaking water bath at $37^{\circ} \mathrm{C}, 90$ cycles/ min, in oxygenated solutions containing the solutes of interest. Saturated solutions of the parent alcohol of steroid were equilibrated 20-24 $\mathrm{h}$ prior to incubation with tissue. Prodrug solutions were freshly prepared. Incubation times were set at 2-5 min. The incubation was stopped by emptying the test tube contents onto a cheeseclothcovered beaker. The tissue was rinsed with cold buffer and blotted dry. Subsequent determination of tissue uptake differed for alcohols and steroids since the former and their prodrugs were available as radiolabeled compounds. In this case, the tissue was weighed in a tared vial, solubilized with $0.5 \mathrm{ml} 30 \% \mathrm{KOH}$ plus $15.0 \mathrm{ml}$ Scintiverse II (Fisher Scientific, Fair Lawn, NJ) and counted by a LS 7500 scintillation counter (Beckman Instruments, Berkeley, CA). Uptake was expressed as $\mathrm{nmol} / \mathrm{min} \mathrm{g}$ wet tissue after subtraction of background activity obtained from tissues not exposed to radioactivity. An HPLC assay was developed for analysis of hydrocortisone, its 21-phosphate and 21succinate esters taken up by intestinal tissue. After sampling of the incubation medium and rapid freezing of the post-incubation tissue to prevent further ester hydrolysis, the samples were transferred to a VirTis freeze- dryer (Gardiner, $\mathrm{NJ}$ ) and sublimated for $48 \mathrm{~h}$. The dry tissue weight was measured and, after pulverization, the powder was acidified with formic acid and extracted three times with ethyl acetate. The three extracts were combined and dried under nitrogen. The residue was reconstituted with acetonitrile and centrifuged prior to HPLC injection. $\left[{ }^{14} \mathrm{C}\right] \mathrm{Hydro}$ cortisone was used in concert with HPLC analysis to verify that no residual drug remained in the white precipitate formed by the addition of ethyl acetate to the acidified tissue powder. Blank tissues were processed as controls for endogenous hydrocortisone levels in gut tissue. Results were expressed as nmol/ min g dry tissue.

HPLC analyses of hydrocortisone, its 21-phosphate and 21-succinate esters

All HPLC analyses were conducted at $254 \mathrm{~nm}$. The mobile phase consisted of $33 \%$ acetonitrile, $67 \%$ acetate buffer $(6.8$ $\mathrm{g} / \mathrm{l})$ and was adjusted to $\mathrm{pH} 3.8$ with 50 $\mathrm{ml}$ glacial acetic acid/l. A $10 \mu \mathrm{m}$, RP-18 Hibar II LiChrosorb column (E.M. Reagents, Gibbstown, NJ) was fitted with a RP-18 guard column (Anspec Inc., Ann Arbor, MI). The instrumental system consisted of a Waters Intelligent Processing System, Model 710B (Milford, MA) interfaced with a Spectroflow 773 Absorbance Detector (Kratos, Ramsey, NJ), Beckman 112 Solvent Delivery Module (Berkeley, CA) and HewlettPackard 3390A Integrator (Avondale, PA).

\section{Statistical treatment of tissue uptake results}

Tissue uptake of solute at the same concentrations were pooled from individual rings and different rats. The mean \pm the standard error of the mean (SEM) and linear regression parameters, as applicable, are reported.

\section{Tissue integrity under experimental conditions}

Tissue handling and incubation times were deliberately minimized in order to promote 
tissue viability. Tissue integrity was assessed by two means. Extracellular water (ECW) changes were examined using $\left[{ }^{14} \mathrm{C}\right] \mathrm{PEG}$ 4000 in the incubation medium of the following (all incubations at $37^{\circ} \mathrm{C}$ ) to monitor development of mucosal cell leakiness [15]: (a) controls, incubated with buffer for 3 , 6 and $12 \mathrm{~min}$;

(b) $0.25,0.40$ and $0.55 \mathrm{mM}$ hydrocortisone solutions incubated for $6 \mathrm{~min}$;

(c) $0.25 \mathrm{~m} M$ hydrocortisone solutions incubated for 3,6 and $12 \mathrm{~min}$.

Each test solution or time was performed in triplicate and analyzed by the method described for the radioactive alcohols and lysinate prodrugs. In addition, the following specimens were prepared for light microscopy evaluation of both in vitro ring technique and in situ perfusion technique:

(a) control, unperfused intestinal segment;

(b) intestinal segment perfused for $1 \mathrm{~h}$ with buffer, $0.382 \mathrm{ml} / \mathrm{min}$;

(c) everted intestinal ring prepared and immediately fixed;

(d) everted intestinal ring incubated in buffer for $5 \mathrm{~min}$;

(e) everted intestinal ring incubated in 0.25 $\mathrm{m} M$ hydrocortisone-21-succinate for 5 $\min$;

(f) the same as (e) but $10 \mathrm{mM}$ hydrocortisone-21-succinate.

Specimens were fixed in Bouin's solution for at least $24 \mathrm{~h}$, then dehydrated, cleared and embedded in paraffin [20]. Sections of 8-10 $\mu \mathrm{m}$ thickness were made and stained with hematoxylin and eosin.

\section{RESULTS AND DISCUSSION}

\section{Tissue integrity studies}

Extracellular water content, as determined by the nonabsorbable marker, $\left[{ }^{14} \mathrm{C}\right] \mathrm{PEG}$ 4000 , did not change over the time course of the experiments regardless of whether the intestinal tissue was incubated with buffer or different concentrations of hydro-

\section{TABLE 1}

Extracellular water content of jejunum under the experimental conditions of the in vitro intestinal ring procedure. All incubations were performed at $37^{\circ} \mathrm{C}$. This experiment monitored any changes in intestinal tissue leakiness ( $\mathrm{HC}=$ hydrocortisone.)

Sample $\quad \mathrm{ml} \mathrm{ECW} / \mathrm{g}$ tissue

Control, $3 \mathrm{~min}$

Control, $6 \mathrm{~min}$

Control, 12 min

$0.25 \mathrm{mM} \mathrm{HC}, 3 \mathrm{~min}$

$0.25 \mathrm{mM} \mathrm{HC}, 6 \mathrm{~min}$

$0.25 \mathrm{mM}$ HC, $12 \mathrm{~min}$

$0.40 \mathrm{mM} \mathrm{HC}, 6 \mathrm{~min}$

$0.55 \mathrm{mM} \mathrm{HC}, 6 \mathrm{~min}$
$0.206 \pm 0.100$
$0.269 \pm 0.044$
$0.323 \pm 0.123$
$0.146 \pm 0.048$
$0.488 \pm 0.105$
$0.204 \pm 0.035$
$0.203 \pm 0.038$
$0.271 \pm 0.096$

cortisone (Table 1). Calculations based on tissue weight before and after freeze-drying, and results from $\left[{ }^{14} \mathrm{C}\right] \mathrm{PEG} 4000$ experiments indicate that jejunal tissue is approximately $80 \%$ water. This translates into about $20 \mu \mathrm{l}$ total water/ring, of which $30 \%$ is extracellular water.

The results obtained from histology studies performed under in situ and in vitro experimental conditions are presented in Figs. 2 and 3 . Figure $2 \mathrm{~A}$ is a control specimen taken from normal rat intestine. It is contrasted with Fig. 2B, which shows the impact of in situ buffer perfusion through the intestine of the same animal for $1 \mathrm{~h}$. Swelling of the central lacteals of the villi is present in the perfused segment, with some reduction in intervillus space probably due to water absorption. This has been noted for rabbit intestine when lengthy incubation times were used in vitro [21]. The micrograph serves to show, however, that in this steady-state experimental system the functional integrity of the villus is maintained. When examined at higher magnification, this is also true for the brush border (Fig. 2C).

The micrographs presented in Fig. 3 evaluate tissue viability during the in vitro intestinal ring method. The first panel, Fig. $3 \mathrm{~A}$, illustrates the structural condition of the intestine immediately after it has been 

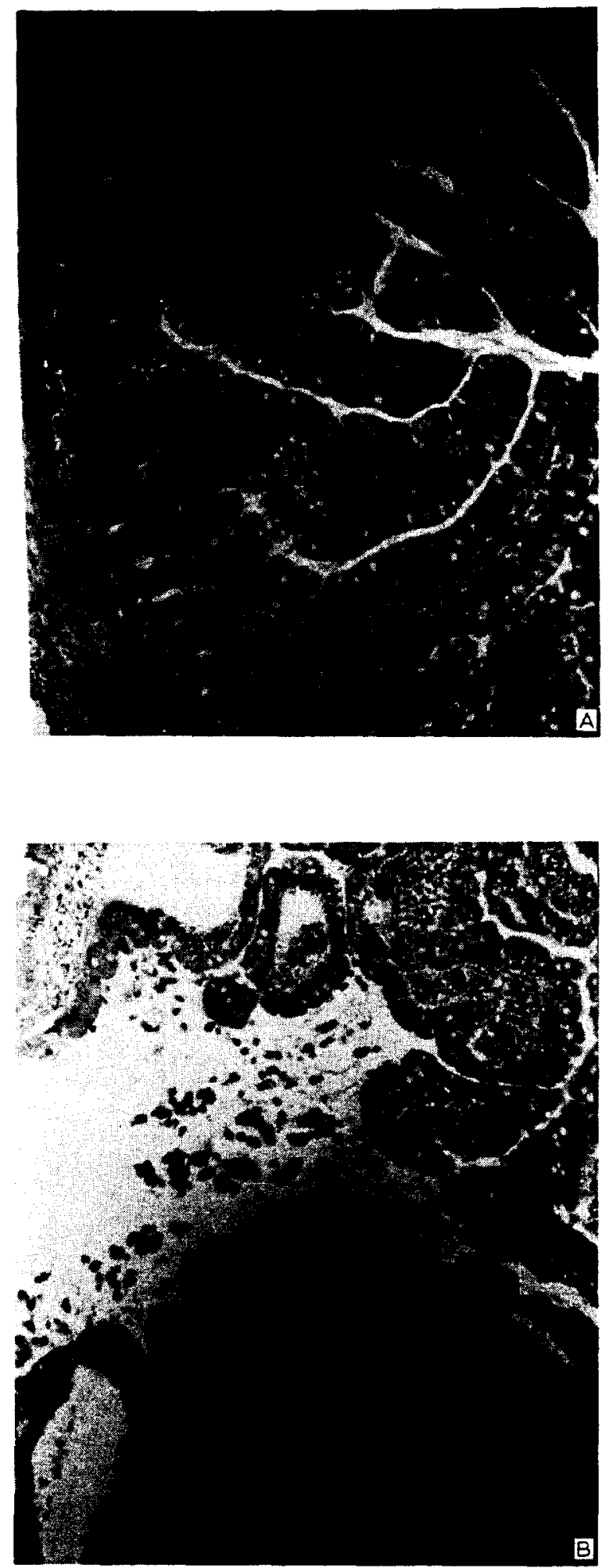

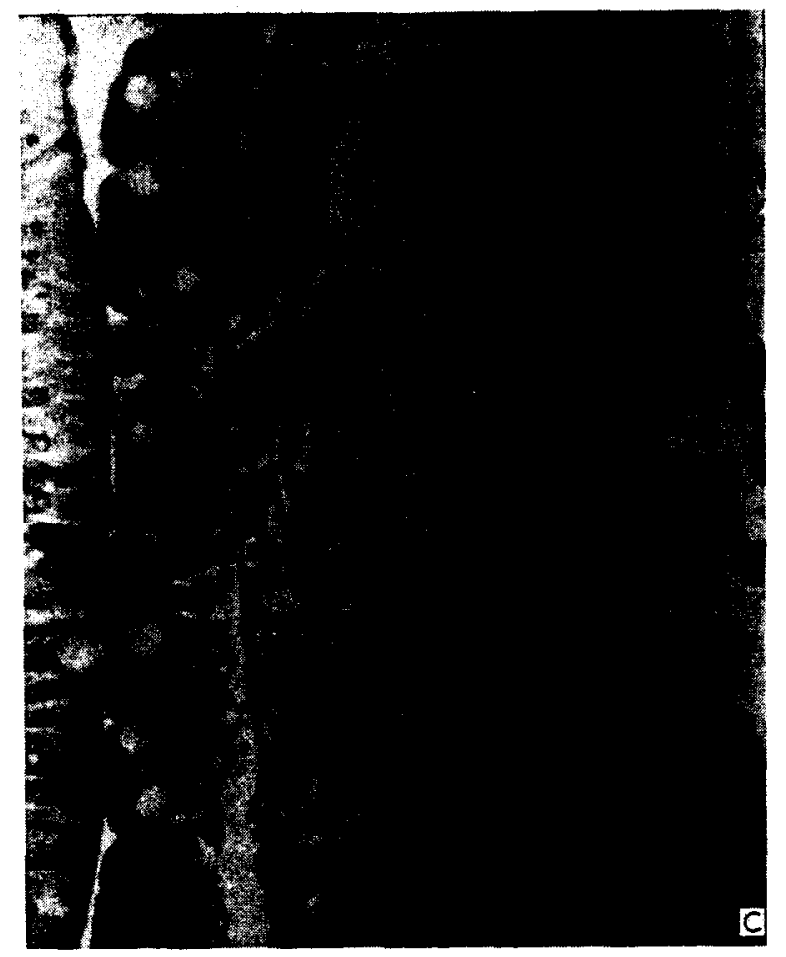

Fig. 2. Normal rat intestine is shown in panel $A$, while panel B depicts the effect of a $1 \mathrm{~h}$ intestinal perfusion of phosphate buffer in the same animal. In the higher magnification in panel $C$, it can be seen that integrity of the brush border is maintained.

excised and everted. The three subsequent panels (Figs. 3B-D) show intestinal segments which have been incubated for $5 \mathrm{~min}$ with either buffer or hydrocortisone-21succinate, with a higher magnification of the higher steroid concentration depicted in Fig. 3E. There appears to be no solute effect at the light microscopy level. The effect of incubation at $37^{\circ} \mathrm{C}$ appears to be a slight thickening of the villi with crowding of the intervillus spaces and, therefore, some change in the surface area available for absorption. Swelling of the central lacteal is not evident here as it was in the perfused segment, probably due to the short time course of the experiment. Again, the gross structures of the villi are maintained as well as the integrity of the brush border. The dimensionless effective intestinal per- 

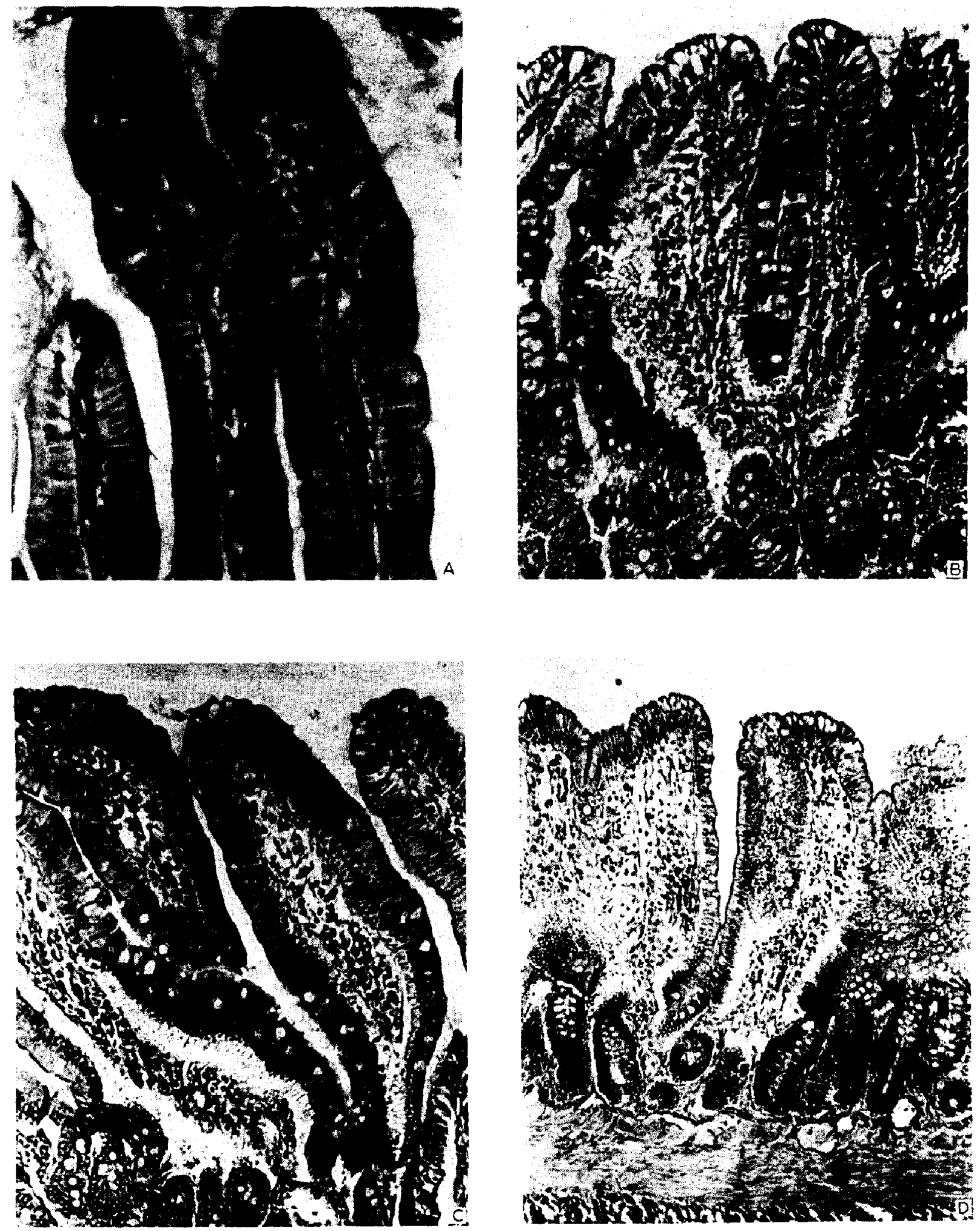

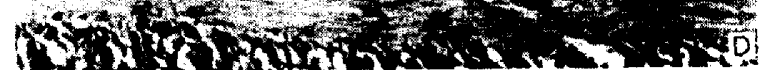




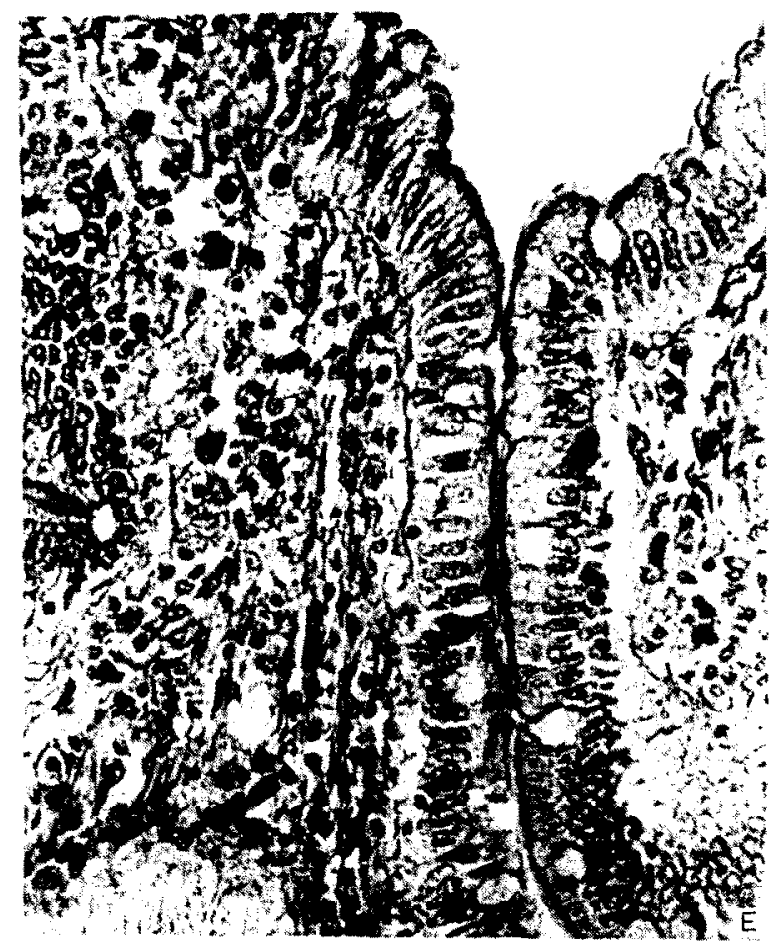

Fig. 3. Panel A shows the condition of the intestine after eversion and immediate fixation. Panels B, C and $\mathrm{D}$ depict specimens incubated for $5 \mathrm{~min}$ at $37^{\circ} \mathrm{C}$ in Krebs-Henseleit buffer, $0.25 \mathrm{mM}$ and $10.0 \mathrm{~m} M$ hydrocortisone-21-succinate, respectively. Panel $E$ is a higher magnification of $D$.

meabilities for decanol and decyl lysinate are summarized in Table 2 . The wall permeabilities, ${ }^{\circ} P_{\mathrm{w}}^{*}$, were very high for both compounds and it is more instructive to note that the effective permeabilities of both compounds are very close. The solution hydrolysis kinetics of decyl lysinate were followed in perfusate and found to be first-order $(r=0.99)$, with a rate constant of $0.0025 \mathrm{~min}^{-1}$. The corresponding halflife is $277 \mathrm{~min}$ which is long with respect to the intestinal residence time,

$t=\pi l r^{2} / Q$

of $3.2 \mathrm{~min}$, where $l$ is intestinal length, $r$ is intestinal radius, and $Q$ is flow rate. Consequently, solution hydrolysis followed by absorption is unlikely. It can be concluded therefore, that while the aqueous solubility

\section{TABLE 2}

Effective intestinal permeabilities obtained from rat perfusions in situ conducted below the solubility of decanol $(0.2 \mathrm{mM})$. Graetz numbers were in the range of $0.01-0.04$.

\begin{tabular}{llc}
\hline Compound & $P_{\text {eff }}^{*}\left(37^{\circ} \mathrm{C}\right)^{\mathrm{a}}$ & Solubility \\
\hline 1.decanol & $5.35 \pm 0.28(n=6)$ & $0.2 \mathrm{mM}$ \\
decyl lysinate & $3.38 \pm 0.50(n=7)$ & $>20 \mathrm{mM}$ \\
\hline
\end{tabular}

${ }^{a} P_{\text {eff }}^{*}$ (dimensionless $)=(R / D) P_{\text {eff }}$ are effective permeabilities $(\mathrm{cm} / \mathrm{s})$ normalized by the ratio of intes* tinal radius $(\mathrm{cm})$ to compound aqueous diffusivity, $P_{\text {eff }}^{*}=5.25=\left(0.2 \mathrm{~cm} / 8.87 \times 10^{-6} \mathrm{~cm}^{2} / \mathrm{s}\right) \cdot(2.37$ $\times 10^{-4} \mathrm{~cm} / \mathrm{s}$ ).

of decanol has been increased by at least a factor of 100 by esterification with lysine, the permeability has not been significantly compromised. It would be unlikely to observe comparable permeabilities between two compounds of such different polarity (i.e., hydrocarbon vs. ionized species) unless hydrolysis of the prodrug has occurred prior to absorption.

The significance of the prodrug's increased solubility without a compromise in intestinal permeability was further investigated in an in vitro intestinal ring system using radiolabeled tracers $[15,16]$. This method permitted study of the uptake process above the solubilities of the two parent alcohols, decanol and hexadecanol. In addition, the in vitro method used short incubation times which maintained tissue integrity, and was advantageous statistically since a large number of data points could be obtained from the same experimental animal.

The mean uptake by intestinal rings is shown for decanol and decyl lysinate as a function of concentration in Fig. 4. At concentrations below the solubility of decanol, the slopes of both curves are comparable, providing agreement with the intestinal permeabilities obtained from in situ perfusions in the same concentration range. Differences in uptake rate increase rapidly with concentration since the parent alcohol remains at 


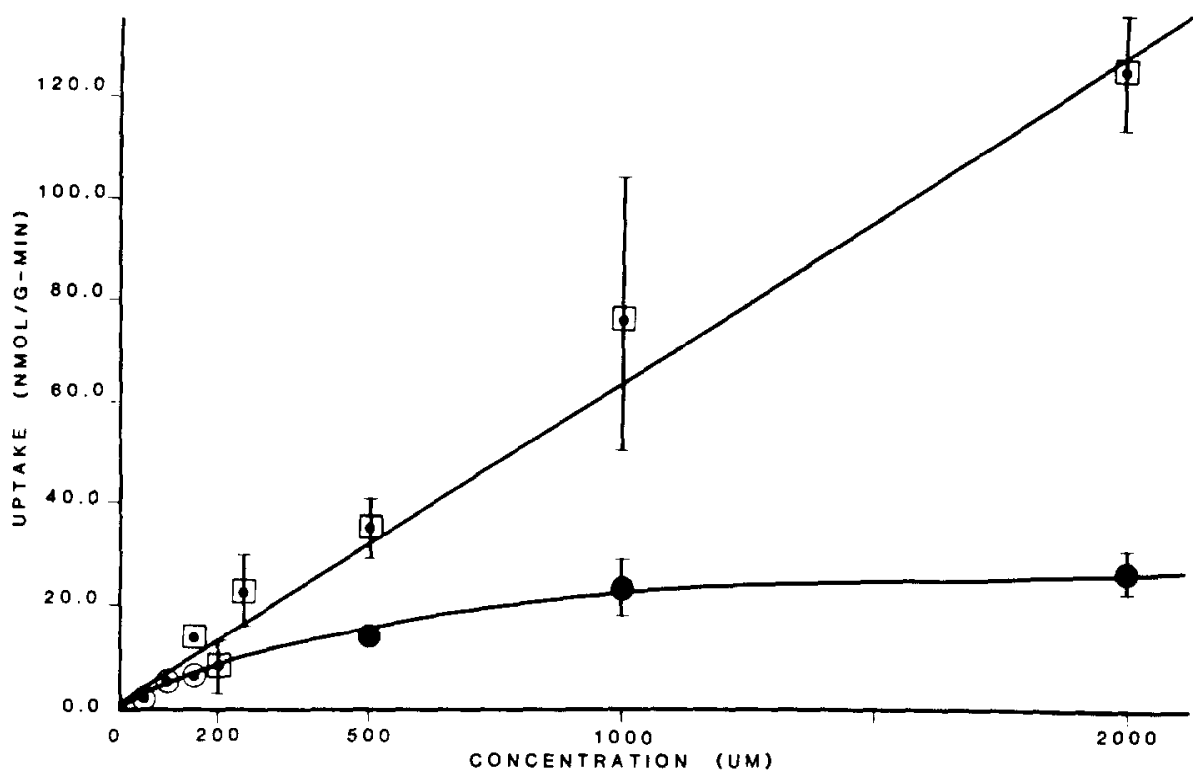

Fig. 4. The intestinal ring uptake of decanol $(0)$ and decyl lysinate $(0)$ as a function of concentration. Values above the solubility concentration of decanol are indicated by $\bullet$. Each point represents the mean value of 2-9 intestinal rings from $2-3$ rats \pm SEM.

the plateau dictated by its lower solubility $(0.2 \mathrm{mM})$ and the lysinate ester maintains a linear increase in uptake over the entire concentration range studied.

Figure 5 depicts a summary of logarithmic intestinal ring uptake of the four compounds at selected concentrations. Values for hexadecanol and decanol are at the respective solubility concentrations or slightly below (0.2 $\mu M$ and $0.15 \mathrm{~m} M$, respectively). The logarithmic differences correspond well with what would be expected on an order-ofmagnitude basis given the concentrations in the incubation medium. The increased aqueous solubilities of the lysinate esters demonstrate the impact of a greater concentration gradient on uptake rate at concentrations at least $10 x$ in excess of the solubilities of the parent compounds. Figure 5 clearly demonstrates that this prodrug approach can be used to greatest advantage for very water insoluble compounds.

Intestinal ring experiments were also conducted with hydrocortisone, the 21-phosphate and 21-succinate esters to (a) clarify

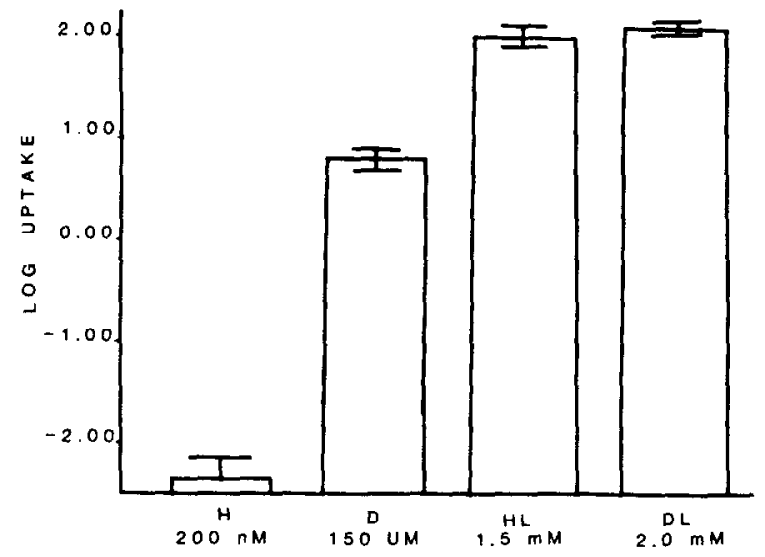

Fig. 5. Logarithmic uptake rates by intestinal rings at selected concentrations. The uptakes are shown at the solubility of hexadecanol $(\mathrm{H})$, slightly below the solubility of decanol (D), and well below the solubilities of the lysinate esters (HL, DL).

in situ/in vitro correlation and (b) ascertain whether drug or prodrug is being absorbed into intestinal tissue. Hydrocortisone was the only species detected in jejunal tissue by HPLC analysis, whether the rings were incubated with drug or prodrug. Unpub- 


\section{UPTAKE Of HYDROCORTISONE and ITS ESTERS}

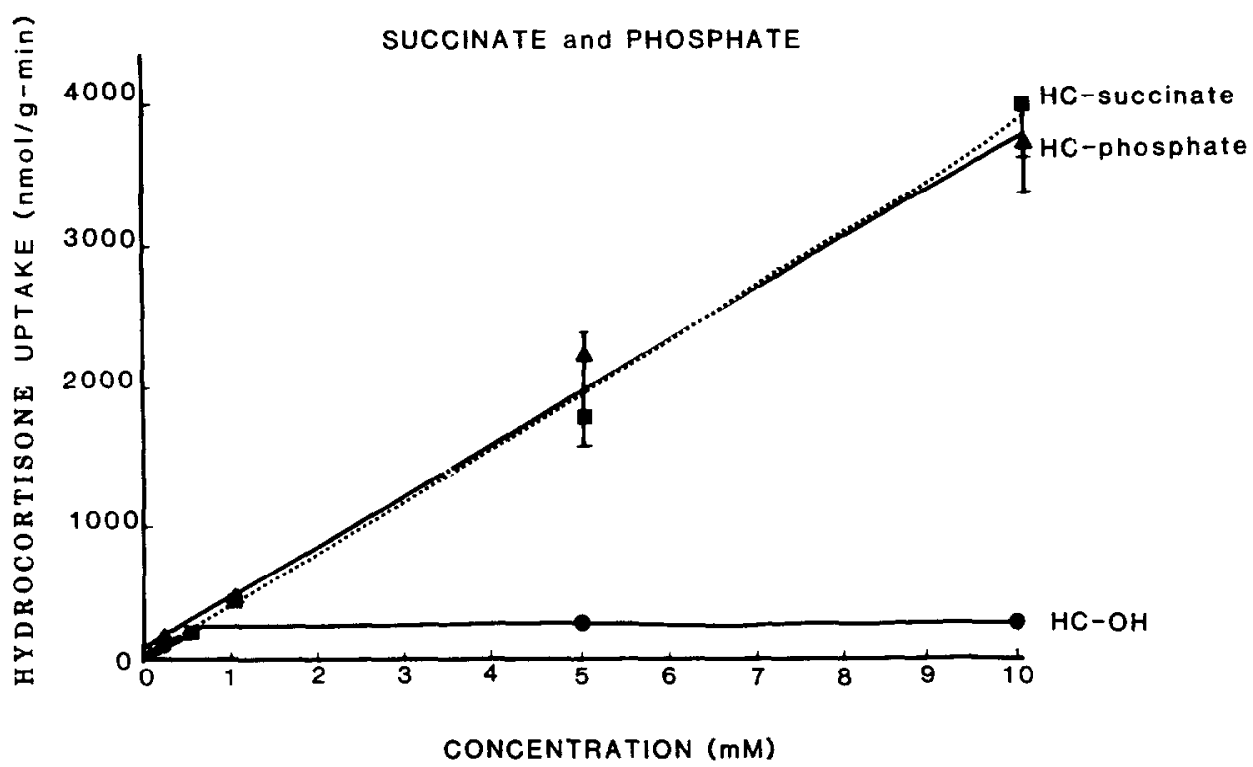

Fig. 6. The intestinal ring uptakes of hydrocortisone ( $\mathrm{HC}-\mathrm{OH})$, hydrocortisone-21-succinate and hydrocortisone-21-phosphate as a function of concentration. Hydrocortisone is a saturated solution at 5 and $10 \mathrm{~m} M$. The prodrugs are freely soluble in the concentration range studied. Each point represents the mean value of $3-15$ intestinal rings from $2-5$ rats \pm SEM.

lished results indicate that uptake of hydrocortisone-21-succinate by proximal colon is in the form of the prodrug ( $>85 \%$ hydrocortisone-21-succinate). The concentration uptake rate profiles shown in Fig. 6 are similar to those presented for decanol and decyl lysinate, i.e., the uptake rate platea! dictated for hydrocortisone is evident beginning at its solubility concentration $(0.77 \mathrm{mM})$ and continues throughout the concentration range studied. Uptake of the 21-phosphate and 21-succinate prodrugs increases linearly with concentration. Ester stability in bulk incubation media and under assay conditions was verified, which emphasizes the conclusion that enzymatic hydrolysis has occurred in concert with intestinal absorption. Hydrocortisone uptake rates are compared with those of hydrocortisone-21-phosphate and hydrocortisone-21-succinate at $10.0 \mathrm{mM}$ incubation media concentrations in Fig. 7. An order of magnitude difference in observed uptake rate is seen between the parent compound and prodrugs.
Theoretical uptake rates can be estimated from the following solution for diffusion through a planar surface in semi-infinite media [22] , (Table 3)

$U_{\text {th }}=2 C_{\mathrm{o}}[D t / \pi]^{1 / 2}(A / m)$

where $U_{\text {th }}$ is the theoretical uptake rate, $C_{\mathrm{o}}$ is the concentration of bulk solution, $D$ is the diffusion coefficient [17], $t$ is time $=120 \mathrm{~s}$, and $A / m$ is the area:mass correlation $=22.6 \mathrm{~cm}^{2} / \mathrm{g}$ wet tissue. $A / m=22.6$ $\mathrm{cm}^{2} / \mathrm{g}$ wet tissue was experimentally determined and is in good agreement with values reported in the literature: $24.0 \mathrm{~cm}^{2} / \mathrm{g}$ [23] and $32.0 \mathrm{~cm}^{2} / \mathrm{g}[24]$. The calculated values are compared with experimentally determined values in Table 3 . The theoretical values range from 4 to $14 \times$ those observed in this study. The uptake model (eqn. 7) assumes sink conditions at the solution-brush border membrane interface, a planar surface, and a constant diffusion coefficient. Surface area effects, as well as a changing diffusion coefficient, might explain these deviations. In an 


\section{log (HYDROCORTISONE UPTAKE)}

\author{
at $10.0 \mathrm{mM}$
}

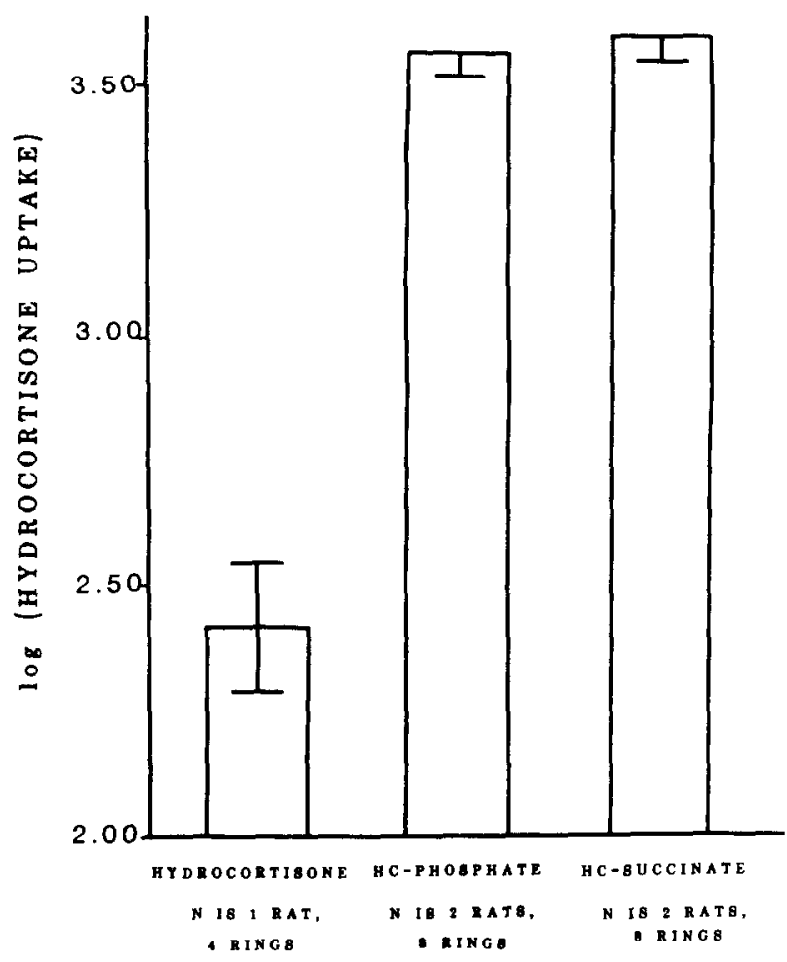

Fig. 7. Logarithmic uptake rates by intestinal rings at $10 \mathrm{~m} M$ incubation medium concentrations of hydrocortisone, hydrocortisone-21-phosphate and hydrocortisone-21-succinate. earlier study, decanol uptake was determined from $0.25-1.0 \mathrm{~m} M$ solutions [21]. When the results were normalized to $C_{\mathrm{o}}=0.15 \mathrm{mM}$, the uptake was $55.8 \mathrm{nmol} / \mathrm{min} \mathrm{g}$ dry tissue, closer to the theoretical rate in our study. This difference may be due to two factors. First, the concentrations used in the latter study were above the solubility of decanol; although no mention of precipitation was made, the possibility exists that a contribution by suspended liquid droplets may have occurred. Secondly, these authors normalized uptake results by dry tissue weight. Since intestinal tissue is approximately $80 \%$ water, this may also account in part for the difference between the two studies. While theoretical and experimental values could be brought into closer agreement by either reducing the diffusion coefficient or relaxing the sink boundary condition at the membrane solution interface, the calculation demonstrates that the observed uptake is comparable to what would be expected theoretically.

The approach taken in this report is based on the known role of brush border enzymes in peptide digestion and absorption $[8,25$, 26 ]. Chemical derivatization of poorly water soluble compounds has been used to target sites favorable to intestinal absorption. It

TABLE 3

Theoretically predicted $\left(U_{\text {th }}\right)$ and experimentally observed ( $\left.U_{\text {ex }}\right)$ uptakes of all compounds are tabulated. Also shown are the estimated diffusion coefficients [17], and concentrations $\left(C_{o}\right)$ at which the rates were determined. Theoretical and experimental uptakes for the alcohols and steroids are not directly comparable as the former rates are normalized by wet tissue mass and the latter by dry tissue mass

\begin{tabular}{|c|c|c|c|c|}
\hline Compound & $\begin{array}{l}C_{\mathrm{o}} \\
(\mathrm{mol} / 1000 \mathrm{ml})\end{array}$ & $\begin{array}{l}10^{6} \mathrm{D} \\
\left(\mathrm{cm}^{2} / \mathrm{s}\right)\end{array}$ & $\begin{array}{l}U_{\text {th }} \\
(\mathrm{nmol} / \mathrm{g} \mathrm{min})\end{array}$ & $\begin{array}{l}U_{\text {ex }} \\
\text { (nmol/g min) }\end{array}$ \\
\hline Hexadecanol & $200 \mathrm{nM}$ & 6.82 & 0.086 & 0.006 \\
\hline Decanol & $150 \mu M$ & 8.87 & 73 & 6.5 \\
\hline Hexadecyl lysinate & $1 \mathrm{mM}$ & 5.15 & 373 & 92 \\
\hline Decyl lysinate & $2 \mathrm{mM}$ & 5.98 & 805 & 125 \\
\hline Hydrocortisone $\mathrm{a}^{\mathrm{a}}$ & $10 \mathrm{mM}$ & 7.22 & 8300 & 1330 \\
\hline Hydrocortisone-21-phosphate & $10 \mathrm{mM}$ & 5.07 & $5.77 \times 10^{4}$ & $1.83 \times 10^{4}$ \\
\hline Hydrocortisone-21-succinate & $10 \mathrm{mM}$ & 4.68 & $5.55 \times 10^{4}$ & $1.97 \times 10^{4}$ \\
\hline
\end{tabular}

${ }^{\mathrm{a}} U_{\mathrm{th}}$ for this saturated solution was calculated using $C_{\mathrm{o}}=C_{\mathrm{s}}\left(37^{\circ} \mathrm{C}\right)=1.10 \mathrm{mM}$. 
may be concluded that making water soluble prodrugs selective for membrane-bound $\mathrm{di}$. gestive or metabolic enzymes systems in the gut can substantially improve the transport of water insoluble solutes into mucosal cells.

\section{ACKNOWLEDGEMENTS}

The authors gratefully acknowledge $\mathrm{Mr}$. Kevin Johnson and Dr. Vincent Atrache for the synthesis of decyl lysinate used in the rat intestinal perfusion experiments, Dr. David Fleisher for performing much of the animal surgery in these experiments and Ms. R. Kay Brabec for histology services. Microanalyses for the nonradioactive dihydrochloride salts of the lysine esters were performed at the University of Kansas, Lawrence, KS. This work was supported in part by NIH grants GM27680 and GM31568.

\section{REFERENCES}

1 J.T. Carstenson, Pharmaceutics of Solids and Solid Dosage Forms, John Wiley \& Sons, New York, 1972.

2 G.L. Amidon, Drug derivatization as a means of solubilization: physicochemical and biochemical strategies, in: S.H. Yalkowsky (Ed.), Techniques of Solubilization of Drugs, Marcel Dekker, New York, NY, 1981, pp. 183-208.

3 V. Stella, Prodrugs: An overview and definition, in: T. Higuchi and V. Stella (Eds.), Prodrugs as Novel Drug Delivery Systems, American Chem. ical Society, Washington, DC, 1975, pp. 1-37.

4 G.L. Amidon, G.D. Leesman and R.L. Elliott, Improving intestinal absorption of water in. soluble compounds: A membrane metabolism strategy, J. Pharm. Sci., 69 (1980) 1363-1368.

5 D. Fleisher, B.H. Stewart and G.L. Amidon, Design of prodrugs for improved gastrointestinal absorption by intestinal enzyme targeting, in: K.S. Widder and R. Green (Eds.), Methods in Enzymology, Drug and Enzyme Targeting, Vol. 112, Academic Press, New York, NY, 1985, pp. $360-381$.

6 Y.S. Kim and E.J. Brophy, Effect of amino acids on purified rat intestinal brush-border membrane aminooligopeptidase, Gastroenterology, $76(1979) 82-87$.
7 S. Miura, I-S. Song, A. Morita, R.H. Erickson and Y.S. Kim, Distribution and biosynthesis of aminopeptidase $N$ and dipeptidyl aminopeptidase IV in rat small intestine, Biochim. Biophys. Acta, 761 (1983) 66-75.

8 S. Auricchio, L. Greco, B. deVizia and V. Buonocore, Dipeptidyl aminopeptidase and carboxypeptidase activities of the brush border of rabbit small intestine, Gastroenterology, 75 (1978) 1073-1079.

9 F. Moog, The lining of the small intestine, Sci. Amer., 245 (1981) 154-173.

10 G.L. Flynn and D.J. Lamb, Factors influencing solvolysis of corticosteroid-21-phosphate esters, J. Pharm. Sci., 59 (1970) 1433-1438.

11 G.L. Amidon, M. Lee and H. Lee, Intestinal absorption of amino acid derivatives: Structural requirements for membrane hydrolysis. J. Pharm. Sci., 72 (1983) 943-944.

12 G.L. Amidon, M. Chang, D. Fleisher and R. Allen, Intestinal absorption of amino acid de rivatives: Importance of the free amino group, J. Pharm. Sci., 71 (1982) 1138-1141.

13 H. Shindo, K. Fukuda, K. Kawai and K. Tanaka, Studies on intestinal absorption of pivampicillin and species difference in the intestinal esterase activity, J. Pharm. Dyn., 1 (1978) 310-323.

14 G.L. Amidon, S.H. Yalkowsky and S. Leung, Solubility of nonelectrolytes in polar solvents II: Solubility of aliphatic alcohols in water, J. Pharm. Sci., 63 (1974) 1858-1866.

15 B. Cheng, F. Navab, M.T. Lis, T.N. Miller and D.M. Matthews, Mechanisms of dipeptide uptake by rat small intestine in vitro, Clin. Sci., 40 (1971) 247-259.

16 J.W.L. Robinson and G. vanMelle, Single-site uptake of neutral amino acids into guinea pig intestinal rings, J. Physiol., 323 (1982) 569-587.

17 R.C. Reid, J.M. Prausnitz and J.M. Sherwood, The Properties of Gases and Liquids, McGrawHill, New York, NY, 1977.

18 G.L. Amidon, J.H. Kou, R.L. Elliott and E.N. Lightfoot, Analysis of models for determining intestinal wall permeabilities, J. Pharm. Sci., 69 (1980) 1369-1373.

19 R.L. Elliott, G.L. Amidon and E.N. Lightfoot, A convective mass transfer model for determining intestinal wall permeabilities: Laminar flow in a circular tube, J. Theor. Biol., 87 (1980) $757-771$

20 G.L. Humason, Animal Tissue Techniques, W.H. Freeman and Co., San Francisco, CA, 4th edn., 1979.

21 H. Westergaard and J.M. Dietschy, Delineation of the dimensions and permeability character istics of the two major diffusion barriers to passive mucosal uptake in the rabbit intestine, J. Clin. Invest., 54 (1974) 718-732. 
22 J. Crank, The Mathematics of Diffusion, Oxford Univ. Press., Bristol, England, 1975.

23 R.B. Fisher and D.S. Parsons, The gradient of mucosal surface area in the small intestine of the rat, J. Anat., 84 (1950) 272-282.

24 G.N. Gray, Carbohydrate absorption and malabsorption, in: J.R. Johnson (Ed.), Physiology of the Gastrointestinal Tract, Raven Press, New York, 1981, pp. 1063-1072.

25 E. Taylor, D. Burston and D.M. Matthews, Influx of glycyl sarcosine and L-lysyl-L lysine into hamster jejunum in vitro, Clin. Sci., 58 (1980) 221-225.

26 F.W. Schmidt, Enzymological aspects of the gut, Clin. Biochem., 12 (1979) 245-247. 